\title{
A “AVOENGA E QUINHENTISTA INSTITUIÇÃO SERVIL”: DEBATES SOBRE ESCRAVIDÃO NA PRIMEIRA LEGISLATURA POR VOTO DIRETO NO BRASIL (1881-1884)
}

\begin{abstract}
Alexandra do Nascimento Aguiar ${ }^{1}$
A Reforma eleitoral de 1881 introduziu a eleição direta no Brasil e compôs a Câmara dos Deputados com situação e oposição, respectivamente, os partidos Liberal e Conservador em números expressivos e equilibrados ${ }^{2}$. Quadro parlamentar inusitado, lembrando o predomínio das Câmaras unânimes no Segundo Reinado. No entanto, as divergências partidárias foram deixadas de lado à medida que a emancipação retornava ao Parlamento como questão imposta pelos Gabinetes e sob o aval do Imperador.

A eleição de 1881 significou o retrocesso do abolicionismo, sinalizado pela derrota de seus candidatos e pela reduzida intensidade das manifestações dos clubes abolicionistas $^{3}$. A Câmara que resultou da reforma eleitoral de 1881, ou Lei Saraiva, foi formada, em sua maioria, pelos principais representantes da lavoura e próescravatura. Ainda durante os debates sobre o projeto de reforma eleitoral, em 1880, a Revista Illustrada dedicou uma de suas capas a Martinho Campos, escravista assumido e deputado pelo Partido Liberal que se tornaria o primeiro presidente da Câmara eleita por voto direto e, em seguida, o presidente do Conselho.
\end{abstract}

\footnotetext{
${ }^{1}$ Doutora em História pela Universidade do Estado do Rio de Janeiro. Docente do Ensino Médio na Secretaria de Estado de Educação do Rio de Janeiro. E-Mail: <alexaaguiar13@gmail.com>.

${ }^{2}$ Foram eleitos 75 deputados do Partido Liberal e 47 deputados do Partido Conservador. BARÃO de Javary. Organizações e programas ministeriais desde 1822 a 1889. Rio de Janeiro: Imprensa Nacional, 1889.

${ }^{3}$ CONRAD, Robert. Os últimos anos da escravatura no Brasil (1880-1888). Rio de Janeiro: Civilização Brasileira, 1978, p. 206.
} 


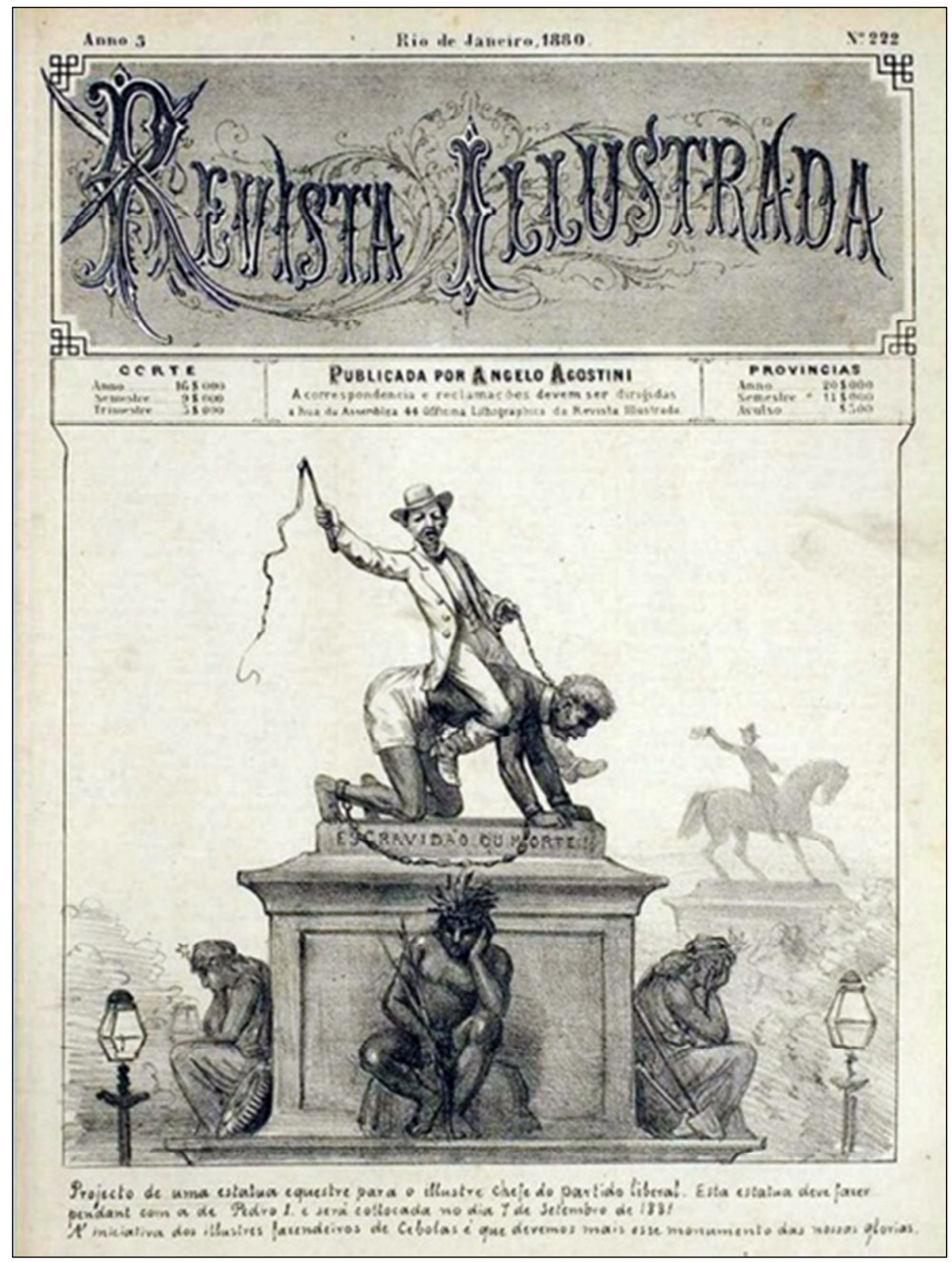

Figura 1 - Revista Illustrada, 04 set. 1880.

Nela, Martinho está empunhando a chibata e montado sobre um escravizado, na base do monumento lê-se "Escravidão ou Morte". Sob a gravura na revista havia a seguinte legenda: "Projeto de uma estátua equestre para o ilustre chefe do Partido Liberal. Esta estátua deve fazer pendant com a de Pedro I e será colocada no dia 7 de setembro de 1881. À iniciativa dos ilustres fazendeiros de Cebolas é que devemos mais esse monumento de nossas glórias". Uma referência ao monumento situado no 
largo do Rocio ${ }^{4}$, erguido em homenagem à Independência e encomendado por Pedro II em 1862. No monumento, D. Pedro I é representado montado sobre o cavalo e em gesto de saudação.

Joaquim Nabuco foi um dos derrotados para a $18^{\text {a }}$ legislatura e decepcionado com os resultados da reforma eleitoral, pois os abolicionistas viram nos eleitores urbanos privilegiados, camada sem vínculo direto com a lavoura, a chance de fortalecer o movimento e que não se concretizou. A maioria dos candidatos abolicionistas foi derrotada nas urnas ou não obteve reconhecimento do diploma eleitoral, excetuando Bezerra de Menezes (PL-Corte) $)^{5}$ e José Mariano Carneiro da Cunha (PL-PE) ${ }^{6}$. Na campanha para a legislatura seguinte (1884), Nabuco denunciaria a Câmara de 1881 como supremacia dos proprietários rurais, "o Parlamento converteu-se num grande Congresso Agrícola, por alguns lugares dados às cidades que representam a inteligência $e$ a intuição nacional, cem foram dados em penhor à escravidão, entregues ao monopólio territorial" ${ }^{7}$. O Brasil era um reino organizado e comandado pela aristocracia rural que justificava seu lugar social com a tradição $e$ as necessidades de subsistência da nação.

Em 1882, os discursos do imperador para a abertura e o encerramento oficiais da Câmara enfocaram as reformas eleitoral e judiciária, não mencionando a escravidão como indicação de trabalho legislativo. O tema surgia transversal aos debates de outra natureza, ora por deputados isolados que chamavam a atenção sobre o assunto; ora em reação ao programa de governo de Paranaguá que o incluiu sem avançar. Durante o ministério, o deputado Zama chamou a atenção contra o silenciamento sobre a questão servil na Câmara:

Não é com silêncio que se previnem as convulsões sociais que se tem dado em outros povos. Ideias desta natureza quando comprimidas e abadadas, produzem, como a pólvora, explosões cujas consequências a ninguém é dado prever.

Era, portanto obrigação, quer do governo, quer desta Câmara saída do voto direto e que se julga legítima representante do país, tratar da ideia que tivesse mais ou menos relação com a solução do grande problema da abolição da condição servil. [...] Se o não fazemos não é porque não seja essa aspiração das nossas alma; se o não fazemos é porque somos representantes dos interesses alheios, a que devemos atender sem abalar os fundamentos da sociedade que representamos. (Apoiados)

\footnotetext{
${ }^{4}$ Hoje Praça Tiradentes, localizada na região central da cidade do Rio de Janeiro.

${ }^{5}$ Para identificar os deputados, optei por apresentar os partidos através das siglas PL (Partido Liberal) e PC (Partido Conservador), seguido da sigla da província/estado representada pelo deputado (CE, SP, RJ, BA, etc.). Exceção para a Corte, o município neutro do Rio de Janeiro.

${ }^{6}$ ALONSO, Angela. Flores, votos e balas: o movimento abolicionista brasileiro (1868-1888). São Paulo: Companhia das Letras, 2015, p. 176-177.

7 NABUCO, Joaquim. Campanha abolicionista no Recife (Eleições de 1884). Discursos de Joaquim Nabuco. Propriedade da Comissão Central Emancipadora. Rio de Janeiro: Typ. de G. Leuzinger e Filhos, 1885, p. 32.
} 
No ardor da discussão o nobre deputado chegou até a exclamar: depois da lei de 28 de setembro neste país não existe mais escravidão.

Pode o nobre deputado negar a luz do dia, pode negar as trevas da noite, mas pode negar a Deus se quiser, mas não pode negar que neste vasto império, [...] existem milhares de infelizes que são cousas e não pessoas, que são instrumentos do trabalho e da fortuna de seus semelhantes, e sem parte alguma nos gozos da vida... ${ }^{8}$

Não havia silêncio na Câmara sobre a emancipação, o problema era abordado de forma limitada, como ampliação da Lei de 28 de setembro de 1871 através de impostos e pelo aumento do controle sobre a propriedade escrava. Porém, tais propostas circulavam mais como rumores e eram tratadas como impertinentes naquele momento econômico e de prejuízo para a lavoura.

Contudo, a partir de 1883, a emancipação voltou à fala do trono, reintroduzido como debate obrigatório na Câmara e demandando novas ações. A primeira comunicação em que Pedro II inseriu a emancipação soava como apelo ao humanitarismo dos deputados, "fazendo justiça a vossos sentimentos, espero que não vos esquecereis da gradual extinção do elemento servil"' . No discurso seguinte, em 1884, ele endureceu o tom diante da omissão da Câmara, "pende de vossa deliberação uma proposta do governo, em que se vos pede a decretação de medidas que dizem respeito ao elemento servil" ${ }^{\prime 10}$. A advertência ressaltou a gravidade da questão e, para não alarmar os parlamentares, apontava a Lei do Ventre Livre como referência para solução e lembrava o empenho do governo na colonização espontânea. A carta de Rodolfo Dantas para Rui Barbosa insinua que houve a participação pessoal de Pedro II na elaboração do projeto que entraria em votação: "Por motivos que te darei quando vieres, o velho é levado no que se refere à localização a contentar-se com a provincial, e a ficar nesta. Convém, pois, modificarmos nesse sentido o projeto. Manda-me as notas do imperador, com a carta do Otoni" 11 .

A fala do Imperador trazia a emancipação para a Câmara como pauta de governo como não acontecia desde 1871, entretanto, na década de 1880 esta também havia se tornado causa pública. Os três primeiros Gabinetes orientaram a emancipação de acordo com a inclinação da presidência do Conselho e sem intensificar ações sobre o problema, relegando o tema que integrava o programa liberal. Martinho Campos ignorou a questão $e$, quando foi pressionado, declarou-se francamente escravista. Paranaguá incluiu a emancipação em seu programa, porém não aprofundou porque esteve sob a rejeição maciça da oposição desde o início e não conseguiu aglutinar

\footnotetext{
${ }^{8}$ Anais da Câmara dos Deputados, 11 set. 1882.

${ }^{9}$ Fala do Trono, 03 mai. 1883.

${ }^{10}$ Fala do Trono, 03 mai.1884.

${ }^{11}$ LACOMBE, Américo Jacobina. Correspondência de Rodolfo E. de Sousa Dantas. Rio de Janeiro: Casa de Rui Barbosa, 1973, p. 113.
} 
correligionários em torno da ideia. Lafayette não ofereceu alternativa além das conhecidas, localização e fundo de emancipação.

Vale retornar ao ex-presidente do Conselho, Martinho Campos, no Senado em 1884, que se notabilizaria pela oposição ao abolicionismo. Em 1882, Martinho Campos foi confrontado sobre a ausência de iniciativas emancipacionistas por parte de seu Gabinete. Lembrado de que tinha imagem negativa junto aos abolicionistas e que era obrigação dele, Martinho, como chefe do governo atender a reivindicação da opinião pública sobre o fim da escravidão. Martinho Campos questionou a concepção de opinião pública:

Mas onde está esta opinião pública? Na maioria do Parlamento? Está na maioria da nação, como dizem os nobres deputados? Mas como é que se conhece essa maioria da nação? É por meia dúzia de moços ou velhos maníacos que escrevem nas gazetas? Esses é que são a opinião pública? Pois, declaro a $V$. Ex. que eu não vivo só nas confeitarias da Rua do Ouvidor, vivo também no Brasil e conheço um pouco a opinião do país. Não há nada mais fácil do que cada um recomendar a sua opinião dizendo que é pública. Por onde o sabem? ${ }^{12}$

Martinho Campos criticava o sentido estritamente urbano $e$ intelectual dado à opinião pública e excludente com os habitantes e proprietários das áreas rurais. $\mathrm{Na}$ visão conservadora, estes eram o país real, a verdadeira opinião pública cujas ideias também circulavam através de jornais e adentravam a Câmara afirmando o oposto da minoria letrada das cidades.

Em 1884, o abolicionismo se revigorou e ganhou as ruas da capital, visível no público presente nas manifestações abolicionistas em espaço aberto $e$ no apoio ao ativismo que consumia panfletos, frequentava peças teatrais, aplaudia ações de libertação e hostilizava políticos escravistas confessos ${ }^{13}$.

\section{Escravidão: Laços e Autoridade}

Manuel Pinto de Sousa Dantas assumiu o Gabinete em 06 de junho de 1884, indicado após Saraiva ter recusado a presidência pela terceira vez. A trajetória de Dantas trazia sólida experiência em cargos no judiciário e político-administrativo $e$ incluía ser membro da Sociedade Libertadora 7 de Setembro, além de notabilizar-se como reformista ${ }^{14}$. A relação de Manuel Dantas com o abolicionismo pode ser problematizada a partir da análise de Emília Viotti da Costa, que não via relação direta e definitiva entre o pertencimento aos grupos agrários e a defesa da escravidão, ou coerência entre as conviç̧ões e as atitudes sobre a abolição. O próprio Dantas fazia parte do universo dos fazendeiros da Bahia e possuía relação com os fazendeiros

\footnotetext{
${ }^{12}$ Anais da Câmara dos Deputados, 28 fev. 1882.

${ }^{13}$ Ver: ALONSO, Flores, votos e balas...

${ }^{14}$ ALONSO, Flores, votos e balas..., p. 239.
} 
fluminenses através de laços familiares ${ }^{15}$. Cabe lembrar também que ele pertencia às elites de região com lavoura economicamente enfraquecida e, portanto, a escravidão havia se tornado menos essencial ${ }^{16}$.

A atitude dos fazendeiros em relação à emancipação é contraditória. Alguns se posicionaram favoráveis à abolição, porém puniam os escravos fugidos $e$ recapturados com o tronco e se recusavam a libertá-los, enfrentando os abolicionistas. Outros se mantiveram contrários à abolição e se converteram apenas durante a votação da Lei Áurea.

Os três meses de duração do ministério Dantas foram de intensificação de representações que chegavam à Câmara através de deputados dos dois partidos, enviadas pela opinião pública reconhecida por Martinho Campos. Estes davam voz aos lavradores, negociantes, médicos, advogados, comerciantes, eleitores; às famílias $e$ aos grupos de indivíduos, aos analfabetos representados por amigos; aos clubes da lavoura, às Câmaras Municipais $e$ às associações comerciais $e$ industriais. Reclamavam a intervenção do Estado para proteger a "ordem pública" contra a "insurreição de escravos"17 instigada por "esse punhado de aventureiros"18 que não respeitava a "avoenga e quinhentista instituição servil" ${ }^{19}$. A simplicidade de tal queixa expressava a percepção sobre o progressivo desmonte do sistema escravista como quebra das relações tradicionais de subordinação:

Usamos de um direito [...], não na linguagem de quem implora, senão na de quem tem o direito de ser ouvido $e$ atendido.

Se é dado ampliar as disposições dessa lei para o fim de aumentar os efeitos legais, na parte atinente às alforrias, do mesmo modo cumpre não afrouxar os laços de respeito $\underline{e}$ obediência, que ela tão solenemente nos prometeu manter $e$ quiçá afirmar. [...]

Se, porém, a vossa missão é simplesmente fazer ato de presença no seio da Câmara para darmos ao mundo um simulacro de representação nacional, indigno de um povo

\footnotetext{
${ }^{15}$ CARVALHO, José Murilo de. A construção da ordem: a elite política/ Teatro de sombras: a política imperial. 4. ed. Rio de Janeiro: Civilização Brasileira, 2008, p. 318.

${ }^{16}$ COSTA, Emília Viotti da. Da senzala à colônia. 4. ed. São Paulo: Editora da UNESP, 1998, p. 442.

17 "REPRESENTAÇÃO a que se referiu o Sr. Almeida Nogueira no seu pedido feito na sessão de 03 do corrente". Anais da Câmara dos Deputados, 04 jun. 1884. Outra representação da Câmara Municipal de Boa Esperança apresentada pelo deputado Soares (PC-MG) mencionou o movimento abolicionista como "sublevando, por sua imprudentíssima propaganda, os instintos ferozes dos escravos contra a classe pacífica dos lavradores, ao ponto de perigar a segurança individual dos mesmos e de suas famílias...". REPRESENTAÇÃO. Anais da Câmara dos Deputados, 22 jul. 1884.

18 "REPRESENTAÇÃO a que se refere o Sr. João Penido na sessão de hoje". Anais da Câmara dos Deputados, 25 ago. 1884.

${ }^{19}$ Representação a que se refere o Sr. Vaz de Mello no seu discurso de hoje. Anais da Câmara dos Deputados, 25 de agosto de 1884.
} 
livre, repousai, então, em as vossas poltronas nos braços da abolição ${ }^{20}$.

Os "laços de respeito e obediência" estavam ameaçados pela extensiva emancipação que incluía mais grupos no rol da cidadania. Até então, as relações de submissão social eram transferidas entre as gerações como parte da propriedade: os empregados, a família, os agregados, a escravaria obedeciam ao novo patriarca ou ao novo dono como ao anterior. Na medida em que a emancipação dos antigos escravos pelo Estado os desobrigava da obediência legal ao ex-proprietário, enfraquecia a autoridade tradicional deste sobre os demais. Os escravos percebiam que o controle exercido pelo proprietário não contava mais com o assentimento do Estado, afetando as relações sociais e de produção imbricadas na sociedade escravista, "atacada à propriedade servil em sua disciplina e, portanto arrancada a seus hábitos de obediência e respeito, desmantelado está o mecanismo econômico deste país" ${ }^{21}$.

As novas iniciativas para debelar a escravidão por parte dos grupos abolicionistas $e$, mais especificamente, pela Coroa aprofundaram a cisão entre o Estado que não se queria mais escravista e a parcela escravista da sociedade ${ }^{22}$. Esta parcela conservadora via a política emancipacionista como desestabilizadora social porque concedia direitos aos escravos. Ao compreenderem-se portadores de direitos, estes romperiam com a submissão intrínseca do universo escravista e se perceberiam como uma classe de negros, não mais escravos ${ }^{23}$. Esta transição geraria, segundo o receio dos proprietários, um novo tipo de ameaça, a "luta social":

Se tal projeto vingar, o país ficará no caminho da barbárie, da depravação e crueldade dos costumes: o projeto do governo criará um novo mal, desconhecido até agora entre nós, o ódio de raça; ódio intransigente, de senhor contra o escravo, do escravo contra o senhor. [...] Tudo se tem procurado, de

20 "REPRESENTAÇÃO a que se refere o Sr. Barão da Leopoldina e a mesa mandou imprimir". Anais da Câmara dos Deputados, 11 jun. 1884. Grifo meu.

21 "REPRESENTAÇÃO a que se refere o Sr. Barão da Leopoldina e a mesa mandou imprimir". Anais da Câmara dos Deputados, 11 jun. 1884.

${ }^{22} \mathrm{O}$ divórcio entre a sociedade escravista e o Estado transparece nos seguintes fragmentos: "só pelo entusiasmo de abolicionistas intransigentes podem ser aplaudidos e deixar de ser julgados - mais conformes com a índole dos governos autocráticos do que com a do iniciado e jurado pelo fundados do Império e também por todos nós". Representação a que se refere o Sr. Manoel Portella. Anais da Câmara dos Deputados, 01 de agosto de 1884. "Com o mesmo arbítrio com que o governo pensa poder decretar a libertação desses escravos, sem indenização, os proprietários prejudicados poderão exercer arbítrio igual, não cumprindo a lei que os espoliou, não alimentando, nem contratando os serviços desses libertos, porque nenhuma lei pode criar tais obrigações". "DOCUMENTOS a que se refere o Sr. Pereira da Silva no seu pedido de hoje". Anais da Câmara dos Deputados, 25 ago. 1884.

${ }^{23}$ A preocupação com insubmissão dos escravos como tão grave quanto a falta de trabalho fica evidente neste trecho: "De tudo isso resulta necessariamente o que era de aguarda-se nas explorações agrícolas e industriais, a saber: não tanto a diminuição de braços, como, por um lado, a indisciplina das fábricas, agravando-se esta de dia para dia, a ponto de ser bem rara a fazenda, em que o espectro da insurreição não esteja a perturbar dia e noite a tranquilidade..." Representação a que se refere o Sr. Manoel Portella. Anais da Câmara dos Deputados, 01 de agosto de 1884. 
certo tempo a esta parte, promover em benefício da população servil e nada se tem feito para garantir, não a lavoura, mas o Brasil, da ruína de suas finanças, de seu crédito e, mais do que tudo, para evitar uma luta social medonha [... ${ }^{24}$

A primeira legislatura sob a eleição direta foi marcada pela crise entre a Câmara dos Deputados e os Gabinetes que se formaram então, alcançando o ponto máximo no governo de Manuel Dantas, que herdou descontentamentos dos ministérios anteriores. O projeto de libertação dos sexagenários aparece nesse quadro de fragilidade da relação entre as duas esferas e como ação autônoma do Executivo.

O projeto de emancipação dos sexagenários foi mal recebido pelos parlamentares e desencadeou reações de liberais e a formação de coalizão com os conservadores. As censuras de ambos os partidos se referiam ao projeto apresentado como acabado, sem consulta ao legislativo, e a não indenização, considerada um ataque à propriedade. A oposição dentro da Câmara se voltou contra Manuel Dantas, acusado de transitar de emancipacionista para abolicionista, e fora da Casa, seu nome já era combatido como chefe de governo antes mesmo da posse, resistência alimentada pelo Brazil, jornal do Partido Conservador que o associava à agitação nas ruas ${ }^{25}$.

Bento Francisco de Paula Souza (PL-SP) sintetizou a opinião pública das lavouras que considerava a Câmara um veículo de idealização dos projetos de interesse do grupo. Com essa finalidade, o grupo da lavoura apoiou a Lei Saraiva, porém, desejava ir além da Lei do Ventre Livre. Portanto, qualquer movimento no sentido de alargar as medidas dessa lei seria mal recebido pelas duas Casas, Câmara e Senado:

A missão do governo é interpretar as aspirações nacionais, positivamente afirmadas. É o que se pode dizer em relação à lei de 28 de setembro e a de 9 de janeiro. Neste caso, porém não se acha o projeto que o governo patrocina. Se atentar em todas as manifestações por que se torna conhecida a vontade nacional, ver-se-á que de toda a parte surgem protestos contra o sistema adotado pelo governo para a abolição.

A Câmara dos Deputados lhe é infensa do mesmo modo que o Senado e o Conselho de Estado em sua quase unanimidade. Igualmente manifestaram-se em oposição a ele as corporações que representam os grandes interesses da nação, os interesses agrícolas e comerciais. ${ }^{26}$

\footnotetext{
${ }^{24}$ Documentos a que se referiu o Sr. Pereira da Silva no seu pedido de hoje. Anais da Câmara dos Deputados, 25 de agosto de 1884 .

${ }^{25}$ A atuação do jornal Brazil. Órgão do Partido Conservador e o conservadorismo nesta legislatura foram analisados por AGUIAR, Alexandra do Nascimento. "Têm todos os mesmos ares de família". Ideias conservadora na Assembleia Geral de 1881. Tese (Doutorado em História) Universidade do Estado do Rio de Janeiro, 2016.

${ }^{26}$ Anais da Câmara dos Deputados, 24 jul. 1884.
} 
O projeto dos sexagenários apresentado pelo deputado Rodolfo Dantas (PL-BA) instituía a libertação a partir dos 60 anos de idade e através de outras possibilidades como por omissão de matrícula e por transgressão do domicílio legal do escravo e o já conhecido fundo de emancipação. O liberto que desejasse permanecer na casa de seu senhor deveria ser vestido e alimentado por ele, neste caso, sem obrigatoriedade de remuneração, e caso optasse por deixa-lo poderia contar com o Estado para seu sustento através do juizado de órfãos. O projeto também estabelecia a rematrícula de escravos e o pagamento de uma taxa por cada um, parte desse valor seria destinado para o fundo de emancipação. A proposta visava ainda a localização do escravo, que não poderia ser transferido para outra província, resultando na libertação deste, exceto nos casos de fuga ou de mudança de domicílio pelo senhor. Na matrícula o senhor deveria declarar o valor do escravo e este seria também seu preço de alforria pelo fundo de emancipação; para que não houvesse tentativa de exceder o valor $e$ dificultar a libertação, o projeto estipulava um teto de preço de acordo com a idade dos escravos ${ }^{27}$.

Duas críticas são constantes nas falas dos deputados, a não indenização e a libertação através do fundo de emancipação. A ausência de indenização aos proprietários indispôs os deputados com o Gabinete Dantas não somente pelo prejuízo financeiro, porém pelo significado simbólico dessa proposição. A não indenização retirava do escravo a qualificação de propriedade, passando este a ser compreendido aos olhos do Estado como trabalhador, humanizando-o como era a intenção da propaganda abolicionista. No discurso conservador, os escravos eram identificados ora como propriedade, ora como bárbaros, seres com "instintos ferozes" ${ }^{28}$, ou simplesmente, escravos. O fundo de emancipação significava o desrespeito à autoridade do proprietário, questão desenvolvida neste artigo mais adiante.

Deputados liberais em funções nas comissões ou secretarias na Câmara renunciavam aos cargos em protesto ao projeto de libertação dos sexagenários, como Leandro de Chaves Mello Ratisbona ${ }^{29}$ e Meton da França Alencar ${ }^{30}$, representantes pelo Ceará, província que se destacara por ter abolido a escravidão em março do mesmo ano. Outros deputados entraram em confronto aberto com o governo e se aproximaram do Partido Conservador, atitude exemplificada por Lourenço de Albuquerque $^{31}$ (PL-AL). Os correligionários liberais e a oposição conservadora

27 "Projeto n. 48 - 1884. Elemento servil". Anais da Câmara dos Deputados, 15 jul. 1884.

28 "REPRESENTAÇÃO". Anais da Câmara dos Deputados, 22 jul. 1884.

29 "Aproveito, porém, a ocasião para pedir a minha demissão de membro das comissões de constituição, poderes e justiça civil. Quero nesta matéria a mais plena e completa liberdade. Digo e repito, aceito a discussão, aceito a ideia, acho que não podemos parar, mas quero ter a liberdade de oferecer emendas e de aceitar a questão de confiança, no momento em que o governo propuser, sobre tal ou tal artigo do projeto". Anais da Câmara dos Deputados, 15 jun. 1884.

30 "...não posso acompanhar o governo, e por isso peço a V. Ex. que consulte a casa se me concede a dispensa do lugar que ocupo, pois em tempo pretendo ajustar minhas contas com o gabinete atual". Anais da Câmara dos Deputados, 28 de julho de 1884.

31 "Declaro, francamente, ao nobre presidente do Conselho que, se o seu projeto contiver a ideia de alforriarem-se sem indenização àqueles que tiverem atingido ou atingirem a idade de 60 anos, o meu voto lhe será contrário e conseguintemente hostil ao gabinete". Anais da Câmara dos Deputados, 01 de julho de 1884 . 
impediam a evolução de discussões ou a votação do projeto dos sexagenários através de adiamentos por motivos diversos, estratégia denunciada por Zama (PL-BA), alcunhando tais deputados como "abafadores":

Os abafadores são os nobres deputados que não têm coragem de discutir os assuntos e que querem dar a votação significação que não pode ter. Em nome do governo e em nome da maioria, declaro que qualquer que seja o resultado desta votação, nada importa para a marcha do Gabinete. Isto demonstrará que os nobres deputados o que não querem é tratar da questão relativa ao elemento servil. ${ }^{32}$

A reclamação de José Ferreira Cantão (PC-PA) resume a tensão paralisante na Câmara: "não se discute, Sr. Presidente, assunto algum que não se trate do projeto do elemento servil; não há ato algum da oposição que não seja logo qualificado pelos honrados membros da maioria como uma manobra para se abafar o projeto" ${ }^{33}$. Os deputados se desviavam de outros projetos $e$ interesses regionais $e$ nacionais, deixados à revelia, para obstaculizar ou defender a libertação dos sexagenários.

Parlamentares liberais e conservadores refratários à abolição possuíam discursos semelhantes sobre a escravidão, esta era repudiada e somente tolerada como sustentáculo da economia do país, precisava-se de prazo para substituí-la e preparar o escravo para viver em liberdade. No mesmo dia em que Rodolfo Dantas apresentou o projeto à Câmara, Antônio Moreira de Barros (PL-SP), presidente da Casa, se demitiu em protesto. $\mathrm{O}$ pedido de demissão reforçou a situação de vulnerabilidade do Gabinete Dantas, pois 55 deputados votaram a favor de sua saída, contra 52 que queriam sua permanência. A diferença de apenas três votos significou a prévia da desestabilização e não a vitória do governo contra a dissidência liberal $e$ os conservadores que passaram para o lado de Moreira de Barros.

Nesse mesmo dia, Antônio Felício dos Santos (PL-MG) ofereceu outro projeto que resumia as ansiedades do grupo escravista. Ele propunha a permanência da escravidão até o final do século XIX, com base nos apelos dos agricultores que "contentam-se com 10 anos de posse não perturbada de seus escravos" ${ }^{44}$. Ao defender sua proposta, o deputado interpretou a relação da sociedade no Brasil com a escravidão, tomando como distinção os escravismos estadunidense e brasileiro. A escravidão era uma instituição presente na trajetória dos povos e nações, segundo Felício, a escravidão permitiu a criação de "uma classe de homens que trabalham, enquanto outros pensam", e, citando Aristóteles, "considerou-a uma lei natural". Contudo, a evolução das sociedades não assimilou o escravo, que se tornou "um corpo estranho no organismo político" 35 .

Segundo ele, a escravidão africana foi a "maior e melhor colonização" no Brasil devido à semelhança de clima com a África e à "plasticidade do português", que

\footnotetext{
${ }^{32}$ Anais da Câmara dos Deputados, 23 jul. 1884.

${ }^{33}$ Anais da Câmara dos Deputados, 25 jul. 1884.

${ }^{34}$ Anais da Câmara dos Deputados, 15 jul. 1884.

${ }^{35}$ Anais da Câmara dos Deputados, 15 jul. 1884.
} 
possibilitou a mestiçagem. Nos Estados Unidos não houve tais fatores, em especial o "cruzamento", pois os brancos desprezavam os negros, ao contrário do que ocorreu com os brasileiros, que os aceitavam não apenas como mão de obra, também o fazia por:

Caridade inata do nosso povo, tão bem demonstrada no modo porque os proprietários receberam e tratam os ingênuos, é muito diferente da aristocracia e do utilitarismo de outros povos. Nosso espírito filantrópico é quase a antítese do comercialismo de outras nações exploradoras dos povos inferiores. ${ }^{36}$

O deputado compreendia a escravidão no Brasil como relação de acolhimento dos senhores para os escravos, desenvolvida a partir da mistura de raças no passado colonial e não apenas pelo aspecto econômico. A fusão étnica plasmou uma sociedade que reconhecia o negro como parte dela e fundamentou sua aceitação pelos proprietários como "caridade inata" e "espírito filantrópico". Este humanitarismo, como Felício o via, se devia ao pertencimento de ambos, brancos livres e negros escravos, a mesma matriz lusitana através da mestiçagem. Entretanto, cabia aos negros, como "povos inferiores", o lugar social como escravos porque a sociedade assim necessitava. A emancipação transformaria os escravos em apenas "negros", além do sentido da cor, significaria a definição de lugar social dos homens negros e mestiços pobres na sociedade sem escravidão.

Essa concepção de Felício dos Santos é evidenciada na distinção que ele fez entre escravo e negro, "nos Estados Unidos a legenda era - livremo-nos do escravo a nossa deve ser - emancipemos o negro" ${ }^{37}$. Na sociedade estadunidense o espaço do negro era restrito à escravidão porque não houve a miscigenação que aproximou as raças branca e negra. Segundo o deputado, lá, o negro livre era um incômodo porque perdeu sua função dentro da lógica econômica que levou a sua entrada no país. No Brasil, a relação entre brancos e negros ultrapassou as fronteiras do "comercialismo" devido à mistura racial. O brasileiro não enxergava o escravo apenas no sentido utilitário, daí a preocupação daqueles que se opunham à abolição imediata e defendiam a emancipação porque esta tinha sentido didático e tutelar, segundo o deputado:

É horrorosa a perspectiva de 1.000 .000 selvagens atirados sem freio sobre uma população apenas 10 vezes maior $e$ disseminada em tão vasto território! Eles seriam, amanhã, na melhor hipótese, 1.000.000 mendigos a sustentar porque a luta pela existência e o instinto de conservação, mais provavelmente, os tornaria salteadores. $O$ resultado seria uma luta medonha e o extermínio de uma raça inferior. ${ }^{38}$

\footnotetext{
${ }^{36}$ Anais da Câmara dos Deputados, 15 jul. 1884.

${ }^{37}$ Anais da Câmara dos Deputados, 25 jul. 1884.

${ }^{38}$ Anais da Câmara dos Deputados, 15 jul. 1884.
} 
A fala de Felício dos Santos oferece elementos presentes nas ideias de outros deputados, a escravidão como instituição, a propriedade escrava como direito consuetudinário e a necessidade de tutela dos escravos pelos senhores. Ratisbona (PL-CE) justificava a posse de escravos utilizando referências do passado que fundamentaram as civilizações contemporâneas, "as sociedades antigas tiveram escravidão; entretanto, é nelas que os povos modernos vão procurar as primeiras lições do direito e os modelos da eloquência e da poesia" ${ }^{39}$.

Uma parcela dos deputados criticava o projeto argumentando sobre a relação amistosa entre senhores e escravos que tornava a mediação do Estado desnecessária, como o depoimento de Cantão (PC-PA): "desde muito antes da lei de 28 de setembro nasciam, é verdade, escravos em minha casa; mas não se batizavam como escravos; saiam para a igreja como tais, e entravam para a casa como libertos" ${ }^{40}$. Cantão ressaltava a harmonia dos "seus libertos" em seu lar para mostrar que esta ordem se reproduziria naturalmente na esfera pública pelas mãos dos senhores.

Essa também era a visão de Martinho Contagem (PL-MG), que ingressou como deputado do distrito ${ }^{41}$ de Martinho Campos quando este foi nomeado presidente do Conselho. Contagem defendia o alistamento militar voluntário em oposição ao ministro da guerra, Cândido de Oliveira, que sustentava o compulsório e por sorteio. Durante esse debate, Contagem justificou seu rompimento com o governo trazendo o tema escravidão/emancipação para a discussão:

Mas, Sr. Presidente, sou um tanto afeiçoado à escola creio que de Brutus (riso), que pela pátria esquecia até o amor de pai; eu, pelos altos interesses de meu país, fecho os olhos para o Gabinete e faço-lhes franca oposição, depois da apresentação desse temeroso projeto sobre o elemento servil, no qual enxergo a desgraça do presente. [...] não posso considerar esse projeto, que pode mais tarde produzir bons resultados, como as enchentes do Nilo, mas que incontestavelmente há de produzir e já está produzindo calamidades. ${ }^{42}$

A "desgraça do presente" $e$ as "calamidades" eram alusões ao projeto emancipacionista, sentido pelos senhores como incentivo à desordem e como intromissão do Estado na dinâmica social e econômica das comunidades. Ele interpretava a emancipação tal qual "garantias e direitos civis" aos escravos, que os tornavam "quase cidadãos", prejudicando "famílias que, dispensando-se de todos os prazeres das cidades, levam vida só de trabalho e de economia" ${ }^{43}$.

\footnotetext{
${ }^{39}$ Anais da Câmara dos Deputados, 23 jul. 1884.

${ }^{40}$ Anais da Câmara dos Deputados, 25 jul. 1884.

${ }^{41}$ Cabe lembrar que a Lei Saraiva, ou reforma eleitoral Decreto 3.029 restituiu a divisão eleitoral do Brasil em distritos, antes adotada pela Lei de Círculos de 1855.

${ }^{42}$ Anais da Câmara dos Deputados, 18 jul. 1884.

${ }^{43}$ Anais da Câmara dos Deputados, 18 jul. 1884.
} 
Para Contagem, a escravidão tinha se "adoçado consideravelmente" no Brasil devido às iniciativas dos senhores em alforriar os escravos por conta própria e sem recompensa. Enquanto os "propagandistas" se tornaram abolicionistas após vender seus escravos aos "maus senhores". Insinuação para descontruir a imagem de altruísmo dos militantes do movimento que teriam negociado seus escravos com os escravistas, criticando-os depois de terem lucrado com a transação. Diante da afirmação sobre a doçura da escravidão, o deputado Aristides Spínola (PL-BA) rebateu que a escravidão era tão amarga que nunca poderia ser doce. A afirmativa foi respondida por Contagem:

Oh, Senhores! Tendes porventura a pretensão de acabar com todas as amarguras da vida humana? Tendes porventura a esperança de espalhar a felicidade entre os homens? A vossa tarefa é então por demais difícil: excede os tempos modernos, excede o poder de muitas gerações ainda! Sois impotentes para tanto.

Zama: Mas temos o direito de restabelecer as leis naturais.

Martinho Contagem: - a vossa tarefa, se a encarais assim, é impossível de realizar-se. Depois dos escravos, virão os miseráveis. Primeiro que conquisteis a igualdade absoluta tendes muito que lutar, e haveis de lutar debalde. ${ }^{44}$

Nas considerações de Contagem, não havia porque lutar contra a desigualdade porque era uma característica natural das sociedades em qualquer tempo. Portanto, ao término da escravidão se seguiria outra forma de distinção social, com privilegiados e injustiçados, senão com base no estatuto da liberdade, seria baseada na propriedade.

Contagem traçou um perfil da sociedade rural, seus eleitores, e que contribuiu para a análise sobre como essa parcela percebia a atuação do Estado sobre a escravidão. $\mathrm{O}$ deputado comparou a vida na Corte do Rio de Janeiro à vida nos vilarejos rurais. Na primeira "não há lugar em que o homem se veja mais no deserto do que na Corte. Aqui, vê-se o homem isolado no meio da multidão" ${ }^{45}$. Enquanto nas comunidades rurais, "na província todos se conhecem na paroquia e se estreitam por laços de amizade e fraternidade, que não se rompem para cumprir esta lei" "46, referindo-se ao alistamento compulsório em discussão.

Contagem demonstrou a impotência do Estado perante tais laços sentimentais através de dois casos de alistamento militar em sua província, Minas Gerais. O primeiro episódio, ocorrido no distrito de S. José do Córrego d'Anta, uma multidão intimidou o juiz de paz, rasgou os documentos e nenhum oficial de justiça retornou desde então, "não há conciliação, nem se faz um auto de corpo de delito, é um lugar inteiramente sem autoridade". No segundo, ocorrido na paroquia Maravilhas, as

\footnotetext{
${ }^{44}$ Anais da Câmara dos Deputados, 18 jul. 1884.

${ }^{45}$ Anais da Câmara dos Deputados, 18 jul. 1884.

${ }^{46}$ Anais da Câmara dos Deputados, 18 jul. 1884.
} 
mulheres "armadas de sacos de polvilho, atacaram a mesa, polvilhando os funcionários públicos" 47 encarregados do alistamento.

$\mathrm{O}$ deputado frisou a ausência de crimes nas regiões mencionadas, enaltecendo a autonomia da população que solucionava os conflitos sem recorrer ao Estado, e que era ela quem definia os limites da autoridade estatal. Aristides Zama (PL-BA), empenhado em defender a emancipação, ironizou a descrição de Contagem sobre S. José do Córrego d'Anta, afirmando que se mudaria para lá,

\section{[...] Martinho Contagem: - tomando em consideração o aparte do nobre deputado pela Bahia, devo avisar de que esse bom viver, que lá se tem, nasce de um certo respeito mútuo; porque quando alguém aparece a perturbar a ordem, os outros caem-lhes de pau em cima... (hilaridade) \\ Zama: - Então, tem-me na conta de perturbador? \\ Martinho Contagem: ... de modo que aconselho ao meu nobre amigo que, principalmente depois que se declarou tão abolicionista, não vá a esse lugar. (hilaridade). ${ }^{48}$}

Seguindo o raciocínio de Contagem, os habitantes das aldeias e das paroquias não operavam através da objetividade das leis, por isso, o Estado não conseguia se impor. A autoridade governamental não era reconhecida por seus habitantes, que viviam de acordo com seus costumes e dispensavam a justiça formal e legítima para resolver questões internas. A legislação era uma intromissão do Estado no modo de viver e de sentir da gente das cidades pequenas, pois desconsiderava os casamentos, os filhos, os falecimentos, os festejos que faziam o cotidiano caminhar por si só, marcado pelo tempo do plantio e da colheita. Tais comunidades se orientavam pelas redes familiares, pelas relações sociais existentes desde seus antepassados e pelo sentimento de pertencimento ao lugar desde sempre.

Os dois eventos acima servem para refletir sobre como as leis emancipacionistas foram interpretadas e recebidas pela população local. Para esta, os escravos eram aceitos como parte desse cotidiano, os afazeres domésticos e a confiança da sinhá se misturavam ao trabalho compulsório e à tortura da chibata por tradição. Tal percepção pode ser ilustrada pela crônica Bons Dias, escrita por Machado de Assis e publicada seis dias após a Abolição da escravidão. Na narrativa, o escritor observaria que a continuidade dessa relação senhor-escravo não seria quebrada pela lei, a alforria era compreendida como benevolência do senhor ao seu escravo Pancrácio e não eliminaria antigos hábitos:

Pancrácio aceitou tudo; aceitou até um peteleco que lhe dei no dia seguinte, por me não escovar bem as botas; efeitos da liberdade. Mas eu expliquei-lhe que o peteleco, sendo um impulso natural, não podia anular o direito civil adquirido por

\footnotetext{
${ }^{47}$ Anais da Câmara dos Deputados, 18 jul. 1884.

${ }^{48}$ Anais da Câmara dos Deputados, 18 jul. 1884.
} 
um título que lhe dei. Ele continuava livre, eu de mau humor; eram dois estados naturais, quase divinos. ${ }^{49}$

O personagem da crônica é citadino e tirou proveito do ato benevolente e "espontâneo" para ingressar na política como deputado. Porém, a julgar pela advertência de Contagem ao correligionário abolicionista, é possível acreditar que, neste caso, o Estado teria que se fazer valer pela força nas regiões rurais e ainda assim a lei não entraria no dia-a-dia da população.

Paula Souza (PL-SP), assim como os correligionários mencionados até aqui, rompeu como o governo e se colocou ao lado dos conservadores. O deputado avaliou o projeto de Dantas como abalo para a economia e para a "tranquilidade das famílias", tomando-o como incentivo à questão social. A libertação dos sexagenários havia se fundamentado sobre uma "filosofia sentimental" que ele via como "sentimentalismo perverso" porque não considerava a incapacidade de adaptação dos escravos idosos à condição de homens livres:

Porque esses homens que ele quer beneficiar não compreendem a responsabilidade da liberdade que se lhes quer dar, vão ficar em situação muito inferior àquela que o governo espera e inculca. [...]

Libertar escravos inválidos, incapazes de certa ordem de serviços, sem forças, sem educação, sem pecúlio, desarmados e não preparados para a luta da vida, solta-los no meio da sociedade, sem consciência dos direitos que vão auferir, não é auxiliar a emancipação (apoiados); teremos a sociedade perturbada, teremos a diminuição da riqueza pública [....$^{50}$

O deputado paulista chamava a atenção para a questão social que o Estado e os abolicionistas criavam para a sociedade ao libertar escravizados já quase incapazes, pois isto os empurraria para a indigência. "E o governo, confundindo propositalmente a questão da emancipação com a questão do trabalho quer arrancar do nosso sentimentalismo um voto que não pode assentar no sentimentalismo" ${ }^{\text {"1. }}$.

Segundo ele, a província de São Paulo havia se antecipado ao problema do trabalho vinculando-o à manutenção da ordem, através de um sistema "evolutivo, natural, prudente e lento". Este sistema era a ampliação das estradas de ferro, melhoramentos da infraestrutura e incentivo à imigração ${ }^{52}$, desta forma haveria incremento da produção com o acesso entre as novas terras produtoras e o mercado

\footnotetext{
${ }^{49}$ Gazeta de Notícias, 19 mai. 1888.

${ }^{50}$ Anais da Câmara dos Deputados, 24 jul. 1884.

${ }^{51}$ Anais da Câmara dos Deputados, 24 jul. 1884.

52 "Votou a assembleia provincial uma lei promovendo a introdução de imigrantes, pagando-lhes a passagem e pondo-os ao alcance do proprietário territorial sem ônus, sem dificuldade de espécie alguma. A introdução de imigrantes morigerados em grande número, e a prosperidade destes garantenos a todos tranquilidade social". Anais da Câmara dos Deputados, 24 jul. 1884.
} 
consumidor. O crescimento da produção demandaria mão de obra e a ampla oferta de trabalho naturalmente não deixaria espaço para a desordem social.

Paula Souza via como primordial os escravos identificarem exclusivamente os senhores como os agentes de sua emancipação $e$ nesse sentido o fundo $e$ a intervenção estatal eram prejudiciais. Primeiro porque a emancipação pelo Estado libertava de forma indiscriminada $e$ muitos não mereciam a liberdade por não serem bons trabalhadores, e somente o senhor conhecia bem os seus escravos. Segundo, se a emancipação fosse delegada apenas aos proprietários, os escravos veriam a liberdade como recompensa pelo seu desempenho, criando um compromisso de gratidão destes para seu ex-senhor:

Como a questão do trabalho para nós é a principal, ao mesmo tempo que alforriamos com mãos generosas os nossos escravos [...] atraímos para o nosso lado trabalhadores. Assim obtemos de um lado a felicidade $e$ tranquilidade do escravo, que fica trabalhando no meio de nós, sendo nosso amigo, sem ressentimento algum, contente conosco e considerando-nos seus tutores naturais.

Os libertos trabalham quando são alforriados pela caridade, como se faz em S. Paulo, mas talvez procedam diversamente, quanto o Estado intervir entre o senhor e o escravo. Neste caso o escravo sai de casa aborrecido e revoltado, porque supõe que o senhor se opôs a sua emancipação até que interviesse o governo e impusesse a alforria. ${ }^{53}$

No discurso do deputado paulista, sua província estava à frente do Brasil na transição do trabalho escravo para o livre de maneira favorável à produção e se mostrava autônoma em relação aos problemas que afetavam o país.

Paula Souza tentou desmoralizar o discurso abolicionista do governo, ao estilo santo-de-casa-não-faz-milagres, apresentando dados sobre a emancipação em São Paulo, no Rio de Janeiro e na Bahia, a última era a província de Dantas. Ele considerou a proporção de alforrias em relação à quantidade de escravos em cada uma das três províncias e concluiu que se os paulistas e os fluminenses (a Corte não foi incluída) tivessem libertado na mesma proporção que o governo da Bahia, teriam alforriado metade do que fizeram. Segundo dados sobre as alforrias apresentados pelo deputado:

\footnotetext{
${ }^{53}$ Anais da Câmara dos Deputados, 24 jul. 1884.
} 
TABELA 1

DADOS APRESENTADOS NOS ANAIS DA CÂMARA DOS DEPUTADOS

(24 DE JULHO DE 1884)

\begin{tabular}{|c|c|c|c|}
\hline DADOS DO DEPUTADO PAULA SOUZA & BAHIA & $\begin{array}{c}\text { SÃO } \\
\text { PAULO }\end{array}$ & $\begin{array}{c}\text { RIO DE } \\
\text { JANEIRO }\end{array}$ \\
\hline População escrava nestas províncias & 165.403 & 174.622 & 301.352 \\
\hline Alforrias reais & 2920 & 5390 & 9956 \\
\hline $\begin{array}{c}\mathrm{N}^{\circ} \text { de escravos alforriados se as alforrias de São } \\
\text { Paulo e Rio de Janeiro ocorressem na proporção } \\
\text { realizada pela Bahia }\end{array}$ & - & 3088 & 5343 \\
\hline $\begin{array}{c}\mathrm{N}^{\circ} \text { de escravos alforriados se as alforrias da } \\
\text { Bahia ocorressem na proporção realizada por } \\
\text { São Paulo }\end{array}$ & 5190 & - & - \\
\hline
\end{tabular}

Para o deputado, Rio de Janeiro e São Paulo também superaram a Bahia em emancipação considerando as despesas e o preço do escravo e lembrou que o projeto de localização do escravo havia partido da província paulista, a primeira também a coloca-lo em prática. Portanto, Paula Souza sustentava que já existia um movimento emancipador por parte dos senhores das duas províncias acusadas de "obscurantista" e "refratária". Ele também ressaltou que a província de São Paulo proporcionava "trabalho remunerador" para os ex-escravos, reduzindo os receios dos proprietários sobre a libertação, pois "um dos grandes medos que temos da alforria dos escravos é a falta de educação deles, o que nos pode trazer perturbações sociais".

Antônio Felício dos Santos (PL-MG), que já havia apresentado projeto alternativo para a emancipação, enfatizou a questão pelo aspecto cientificista e de ameaça de radicalização. Seu discurso foi uma resposta ao correligionário por Minas Gerais Afonso Celso Jr., que se referiu aos estados abolicionistas dos Estados Unidos como modelos de desenvolvimento socioeconômico para o Brasil. Felício rebateu as ideias do colega ressaltando que a colonização branca foi o agente do progresso, mesmo nas regiões escravista ${ }^{54}$. Além da desorganização da economia, que precisava de tempo para transitar da grande lavoura para a pequena lavoura, Felício dos Santos chamava a atenção sobre a conduta dos ex-escravos na sociedade:

Seria um perigo para a ordem pública, pela injeção na sociedade de um milhão de selvagens [...]; a ruína quase total dos libertos e, portanto a perda desse elemento de população se faria sentir logo. Na luta pela existência, como entrariam essas hordas de selvagens criados na miséria da escravidão $e$ com todos os vícios da raça? ${ }^{55}$

\footnotetext{
${ }^{54}$ Felício dos Santos exemplificou sobre a África do Sul: "O rio Orange separa a colônia do cabo da Boa Esperança do país dos cafres. Estes estão livres, independentes e estão no seu país natal; os ingleses vieram de outro clima colonizar o sul da África. Ai há trabalho livre nas duas regiões... comparem-se elas e ver-se-á que a raça, a civilização e muitas outras circunstâncias devem influir nas conclusões a tirar de fato dessa ordem". Anais da Câmara dos Deputados, 25 jul. 1884.

${ }^{55}$ Anais da Câmara dos Deputados, 25 jul. 1884.
} 
As ideias de Felício estavam em acordo com as de Paula Souza sobre a inadequação do ex-escravos à vida livre em sociedade, entretanto, se distanciavam quanto ao enfoque sobre o indivíduo escravizado. Para Paula Souza, a escravidão havia tornado os homens despreparados, por isso era necessário mantê-los sob controle através do trabalho para que não caíssem na indigência e no crime após libertos. Felício dos Santos enxergava a raça como o problema, argumentando que os libertos em diversos países abandonaram o trabalho no primeiro momento.

Felício criticou o fundo de emancipação subsidiado por impostos, proposta inadmissivel em uma situação de crise financeira. De acordo com ele, os proprietários libertavam dez vezes mais do que o fundo de emancipação que apenas perturbava o sistema escravista, pois "libertava cegamente, conferindo a alforria ao azar do sorteio, em vez de dá-la aos bons".

O deputado argumentou que a expectativa de vida dos escravos no Brasil era grande, onde as mortes eram frequentes entre os recém-nascidos e até os sete anos idade, porém alcançavam somente $1 \%$ da população escrava entre treze e sessenta anos. Portanto, ele concluía, a mortalidade dos escravos era menor do que a da classe operária europeia, "mais exposta às moléstias do que os nossos escravos, mais bem pensados e alimentados em geral. Basta notar que uma das principais causas de moléstia na classe pobre da Europa, o frio, não opera entre nós".

As colocações de Felício dos Santos receberam apoios entusiasmados dos deputados conservadores Manoel Peixoto de Lacerda Werneck (PC-RJ), Manoel José Soares (PC-MG) e Manoel do Nascimento Machado Portella (PC-PE), especialmente no concernente à relação estabelecida entre ordem, trabalho e raça. Para o deputado liberal, o projeto havia sido elaborado "por quem não conhece as tendências dos nossos escravos, por quem não convive mesmo com o povo..."

Segundo Felício, o governo parecia ignorar que o liberto idoso abandonaria seu ex-senhor porque não compreendia a casa $e$ o trabalho como elementos constitutivos da liberdade. O projeto de Dantas havia sido elaborado sem levar em conta este "impulso natural" da raça em viver a liberdade se entregando à vagabundagem e aos vícios. Por isso, a tutela dos brancos era necessária para garantir a ordem social e para proteger os negros de sua própria natureza.

O deputado mineiro interpretava o apoio dos abolicionistas ao projeto dos sexagenários não porque estes acreditavam em sua eficácia, contudo porque queriam utilizá-lo como ataque à propriedade e combustível para as agitações. O governo Dantas era nocivo porque oferecia subsídio para a radicalização das ruas e "um governo não pode ser agitador, mesmo nas épocas revolucionárias ele deve ser outra cousa... ${ }^{57 " ~ O ~ d e p u t a d o ~ c r i t i c a v a ~ a ~ f r a g i l i d a d e ~ d a ~ l i b e r t a c ̧ a ̃ o ~ p e l a ~ i d a d e ~ p o r q u e ~ o ~}$ governo não tinha como inventariar a idade dos escravos que atingiam sessenta anos porque poucos possuíam registros de nascimento. As matrículas não eram precisas sobre tal informação e apenas traziam uma estimativa da idade do escravo e, na maioria das vezes, não correspondia à realidade.

Para ele, a solução ainda não havia sido encontrada nas medidas emancipacionistas até então, referindo-se à lei de 28 de setembro, ao fundo de

\footnotetext{
${ }^{56}$ Anais da Câmara dos Deputados, 25 jul. 1884.

${ }^{57}$ Anais da Câmara dos Deputados, 25 jul. 1884.
} 
emancipação e à proposta em discussão. Pois, apenas o diálogo entre o Estado e os proprietários e a satisfação das demandas destes levaria à transição do trabalho escravo para o livre. Felício acusava os abolicionistas de rejeitarem seu projeto por avaliarem o do governo como radical devido à negativa de indenização, oferecendo, assim, argumento para aprofundar o radicalismo do movimento e continuar a exigir mais.

A fala de Felício foi complementada pelo aparte de Domingos de Andrade Figueira (PC-RJ), alertando sobre as libertações promovidas pelos presidentes de província do Ceará e do Amazonas como perigo de incitarem ondas de revoltas escravas e que seriam utilizadas como exemplos pelos abolicionistas. A interferência foi bem aproveitada por Felício, "Sr. Presidente, creio que estou no bom caminho. De um lado ouço a opinião dos que querem o status quo, de outro os que pretendem realizar a ideia pelo processo sumaríssimo cearense e amazonense".

\section{Considerações Finais}

O receio ao avanço do abolicionismo, demonstrado nos debates parlamentares, reflete os temores e anseios conservadores sobre as transformações em curso, a partir das discussões sobre a composição da hierarquia na sociedade e o papel do Estado. Os discursos dos deputados expressam a preocupação em preservar as posições de grupo diante da perspectiva de reformas que ampliariam a cidadania e o significado de direito na sociedade, refletindo na redefinição dos sujeitos de poder e da função do Estado.

Os parlamentares aqui apresentados manifestam ideias conservadores ao reafirmarem seus modos de vida, seus costumes, suas relações sociais e econômicas, conjunto compreendido como "estilo de pensamento", de acordo com Mannheim ${ }^{58}$. Deve-se considerar que o conservadorismo adquiriu contornos distintos conforme o lugar e o período. O Brasil, em fins do oitocentos, vivia uma conjuntura interna de problematização da escravidão, pondo em questão a condução da economia, as relações sociais verticais e a composição da cidadania política. Esse "conjunto concreto de circunstâncias" ${ }^{9}$ estimulou reações, especialmente, dos segmentos rurais $e$ de outros urbanos refratários a modificar as estruturas a partir de sua base, a escravidão. Esta não representava apenas mão de obra, sem desprezar a percepção dos proprietários sobre a libertação como prejuízo no investimento da escravaria, entretanto, ressalto o sentido mais amplo de propriedade como visão de mundo. É esse o sentido dado por Felício dos Santos ao defender a proteção do status quo, referindo-se à transformação dessa sociedade provocada pelas medidas emancipacionistas e às leis que o Estado impunha sobre as comunidades, forçando-as a se adaptarem aos novos tempos de trabalho livre e à nova concepção de cidadania.

\section{$\operatorname{son}$}

\footnotetext{
${ }^{58}$ MANNHEIM, Karl. "O pensamento conservador". In: MARTINS, José de Souza (org.). Introdução crítica à sociologia rural. São Paulo: Hucitec, 1981.

${ }^{59}$ MANNHEIM, "O pensamento conservador", p. 102.
} 


\section{RESUMO}

Este artigo tem como enfoque os debates sobre o projeto de emancipação dos sexagenários na legislatura oriunda da Lei Saraiva. Através dos debates parlamentares, propõe-se a analisar as concepções dos deputados sobre a intervenção do Estado na libertação de escravos e na concessão de direitos aos libertos. O objetivo é demonstrar o viés conservador que orientou a conduta de parlamentares da situação $e$ da oposição, respectivamente partidos Liberal $e$ Conservador, contra a reforma servil. Nesse quadro, a expansão da cidadania decorrente da libertação pelo Estado foi recebida como ameaça às relações de comunidade $e$ de obediência intrínsecas das hierarquias tradicionais e que fundamentavam a visão de mundo conservadora no Império brasileiro.

Palavras Chave: Escravidão; Lei Saraiva; Conservadorismo; Câmara dos Deputados.

\section{ABSTRACT}

This paper aims to understand the discussion about the sexagenarian emancipations project in the legislature derived by Saraiva Law. Focuses on parliamentary debates, the text analyse the deputies' conceptions about State intervention in slavery release law and the rights of freed exslaves. The aim is to demonstrate the conservative understanding which was guiding the conduct of all politicians - Conservative Party and Liberal Party - all against the civil reform. In this frame, the expansion of citizenship derived by the prohibited slavery law was thought as a threat for the community relationship and obedience that structured the traditional hierarchy and held the conservative worldview in Brazilian Empire.

Keywords: Slavery; Saraiva Law; Conservatism; Chamber of Deputies.

Artigo recebido em 05 out. 2016.

Aprovado em 06 fev. 2017. 